\title{
Literature and Historiography in Aristotle and in Modern Times
}

It is a well-known fact that the Aristotelian Poetics belongs to that part of the Stagirite's works commonly qualified as "esoteric," that is, the texts written down for the internal use of the academy at which the philosopher taught. This fact is reflected within the tract itself by a structuring that appears erratic in many regards, when considered from the standpoint of an exoteric reader. There are lengthy passages concerning points that are not that difficult to grasp - I am thinking of the chapters which discuss questions of lexis. There are, on the other hand, extremely concise, even elliptical paragraphs concerning questions with regard to which it would have been highly desirable to get some more information - I am thinking in particular of the argumentation by which the central effect of a well-conceived tragedy is introduced: hêdonê, provoked by a previous catharsis of phóbos and éleos, a mechanism which is not at all as evident as it seems to have been to the person who wrote down the tract. ${ }^{1}$ And there are even flagrant contradictions, the most famous being the one between the qualification of Oedipus the King as the best and most beautiful of all tragedies (kallistê tragôedia; 1453a 23) to be found in chapter 13, and the attribution of this predicate to Iphigeneia in Tauris (1454a 8 sq.) in chapter 14, a piece with a happy ending, that is, a device Aristotle judges in chapter 13 (1453a 30-35), with reference to, amongst other texts, the Odyssey, in a rather condescending way to be complying with the illusions about the world and its mechanisms cultivated by the less intelligent readers and spectators. The situation briefly characterized is complicated by the fact that a standard philological procedure, that is, the search for parallel arguments in other works by the author, does not produce many results in this case; the Poetics is a relatively isolated text within the entire oeuvre.

The remarks I will formulate in the following are thus to be considered with an explicit caveat: any interpretation of the Poetics and its most important concepts will remain by necessity thetical or even hypothetical.

\footnotetext{
1 Many specialists believe that the actual text as transmitted was fixed in writing by a pupil (or several pupils) rather than by Aristotle himself (who may then have revised it, without, however, investing too much effort in the process); although the Stagirite's position towards literature is much more welcoming than that of his teacher Plato, literary artefacts ranked rather low within his hierarchy of human-made objects.
} 
There is one concept, namely the eikós (which might be best translated as something that is verisimilar, likely, or probable), which seems to hold a particularly outstanding position within the entire edifice of thought underlying the text. It occurs in the text at a higher frequency than any other of the terms that hold a privileged position, such as mimêsis, kátharsis, sýnthesis ton pragmáton, phóbos, éleos, hêdonê, etc. This eminent role is underpinned by the fact that it is introduced in a passage of peculiarly high importance to the argument in its entirety. In chapter 9, Aristotle establishes two comprehensive categories of texts referring to reality: on the one hand, there are texts that dedicate themselves to representing the "universal" (kathólou), on the other, there are those representing the "particular" (kat'hékaston; 1451b 7). The first category is comprised of philosophical texts, the second one includes literary texts (especially tragedies and epics) and also those texts that render what has really happened, that is, historiographical texts. The conceptual subdivision of this latter category - texts presenting particular items - is established by recourse to the concept of eikós: literary texts have to respect this criterion by necessity; exceptions are of low quality and not even worth the effort of considering on a theoretical level. Historiographical texts, by contrast, may well dispense with this criterion of verisimilitude, since their veracity is guaranteed by the fact that the events represented did, indeed, occur: "until something happens we remain uncertain of its possibility, but what has happened obviously is possible, since, if impossible, it would not have happened" - this is the core argument concerning the entire problem, as can be read in chapter 9 of the text (1451b 17-20). ${ }^{2}$ From a present-day perspective informed by questioning the possibility of representing reality by means of texts, and the stressing of all of textual "reproduction" of the real as being a construction rather than a representation, one could, of course, characterize Aristotle's argument as somewhat naive; the respective theses are, however, rather recent, and it remains to be seen whether a future, post-postmodernist period will continue to accept Hayden White's reasoning unreservedly, or will rather reject it for being somewhat exaggerated.

The eikós, the verisimilar, is, then, according to Aristotle the indispensable characteristic of texts presenting particular persons and particular events without being able to pretend that what is narrated represents real items; it is the characteristic of literary texts, or, to put it precisely, of literary texts that deserve consideration at all. As it cannot be excluded that certain parts of reality (in the sense of events that did factually occur) follow a path of evolution that

2 All quotations are taken from Aristotle. Poetics, edited and translated by James Hutton. New York: Norton, 1982. 
one could qualify as verisimilar, Aristotle allows that poets may have recourse to historical plots when they are thinking of conceiving a tragedy or an epic text (1451b 30 sqq.). This license conceded to poets and writers, which subverts, in a certain way, a separation clearly established previously (literature on the one hand, historiography on the other,${ }^{3}$ underpins the unique role that the concept of verisimilitude holds within Aristotle's conceptualization of what a literary text is. And the central importance of this concept is corroborated by a famous sentence in chapter 24, by which Aristotle advises choosing an impossible element (adýnaton) that is verisimilar (or may be presented as such) rather than a possible element which is not credible (apithanon; 1460a 26 sqq.); he repeats the advice in chapter 25 (1460b 5 sqq.). The exact signification of the underlying thought is not rendered in the text in a precise way - Aristotle does not give any examples of events that are "impossible but at the same time verisimilar." I should like to link this conceptual syndrome to the close relation of the verisimilar and the doxa as established in that same chapter (cf. 1461b 10). And one might add that the acceptance of the traditional mythical stories as true, or at least as possible, is considered by the philosopher to be an important element of dóxa, that is, of generally held views (cf. 1460 b 30 sqq.); as for items that are at the same time impossible and verisimilar, one could thus think of elements taken from the mythical tradition, as., e.g., the existence of sphinxes (in archaic times).

Although Aristotle does not discuss extensively the reasons why he attributes such a visible role to the concept of the verisimilar, one major point can be extrapolated, in my opinion, from the chapter I have been talking about: a fictional story, that is, a story which cannot refer to a reality that would justify what is told, presented, diffused, has to evince a profile that distances it from outright futility. As Aristotle rejects any explicit abstraction with respect to literary texts, such as, for instance, explicit allegorical personifications or extended reflexive or argumentative passages, and advises sticking to a strictly mimetic mode, the only device that can liberate the fictional text from the suspicion of non-pertinence is, consequently, that of bringing it closer to a rendering of the factual by implementing structures the recipients - readers or viewers - are prepared to accept as something that could possibly have occurred, or that may occur in the future, that is, as something that resembles the real or factual, something that is, as we say in all Western vernaculars, "verisimilar" ("vraisemblable," "verosimile," "verosímil," “wahrscheinlich”).

3 It should be stressed that there is a dissimilarity concerning the license to transgress this separation; Aristotle does not say that historians are free to make use of fictional elements or structures of emplotment. 
The verisimilitude that characterizes well-wrought fictional stories not only frees them from the suspicion of non-pertinence, it also confers upon them an intellectual dignity that elevates them to a level higher than that of texts that render the factual; they are philosophóteron (1451b 5), "more philosophical," than historiographical texts because, although, like the latter, they present particular events, they give expression to something more "universal” (kathólou) than factographical texts.

There are endless discussions amongst the specialists as to what textual level is referred to by the "universal" claimed by Aristotle in the above-mentioned context. But the more comprehensive interpretations - claiming that Aristotle has something like a "global view" in mind - as well as the more cautious readings claiming that the "universal" is meant to be no more than the adequate rendering of characters and their deeds ${ }^{4}$-, all these interpretations of the kathólou which is, according to Aristotle, a necessary constituent of literary texts, may be subsumed under the category of the verisimilar. The kathólou which we as recipients are ready to ascribe to a text that we know does not by necessity represent factual events emanates from a sort of isomorphic relation between the causal laws governing the text's actions and the "laws" of human reality, of "life," as we, recipients, conceive them on a level that precedes critical, that is, epistemologically relevant reflection. It is particularly this link to a more abstract level of what we call "real" or "true" that brings literary texts closer to philosophical texts. But I should like to stress that the Stagirite neither says that literary texts would be equivalent to philosophical texts in this respect, nor that they would be at an equal distance to historiographical texts on the one hand, to philosophical texts on the other. Aristotle just says that, put in perspective, they are closer to philosophical texts than historiographical texts are. It would thus be hazardous to reclaim Aristotle in order to substantiate the thesis, widespread in postmodernist literary theory, that literary texts have a cognitive dignity equal to philosophical texts.

This, in a nutshell, is what Aristotle says concerning the eikós in the famous ninth chapter of his tract. It is indeed remarkable that, even though he stresses the importance of this characteristic in almost every other chapter, he does not go into the details of why he deems it so important. That said, Aristotle's position seems to me far superior to those given by certain theoreticians of modern narrative, namely the advocates of literary realism, for the simple reason that Aristotle's text allows readers to construct an acceptable answer to a question that remains

4 - a position, as I might say in parenthesis, that I find not very convincing, because within the frame of a text of fiction, the characteristics of the personages are not something that could exist prior to the text proper, they are an abstraction of their actions. 
unresolved within the poetic tracts emerging in the age of realism: why should one represent the verisimilar, and why not the real, when it comes to presenting a historical scenario? Why should one read Le Père Goriot (1835) rather than a historiographical text on Restauration France; why should one read L'Éducation sentimentale (1869) instead of a text such as, for instance, The eighteenth Brumaire of Louis Napoléon (1852)? The current answer: "because this is more pleasurable an enterprise" may well be pertinent to the novel by Balzac, but certainly not to the text by Flaubert, which is difficult to read; the attribute of "lisibilité" (as it has been called within the structuralists' polemics against the Balzacian model), ${ }^{5}$ however, calls into question truthfulness, a feature ostentatiously claimed by the text ("Ah, sachez-le! Ce drame n'est ni une fiction ni un roman, All is true!") the text a trustworthy rendering of reality, or, rather, a construction of reality conceived with respect to the common readers' somewhat trivial wishes concerning reality? Flaubert's text, to which one could reasonably attribute an authentic verisimilitude, ${ }^{7}$ is not only difficult to read. The fact that there is, in the text, an aporia at the point where one would like to be given an answer to the question, "Why narrate something verisimilar if it is possible to present something that really happened?" provokes speculative functionalizations that indulge in characterizing the text in a way that cannot be called anything other than highly anachronistic: as an exposure of its devices, as autoreferential, etc.

I have allowed myself this first short digression in order to create a background from which the comprehensive Aristotelian argument proper will detach itself in a clear-cut way: the verisimilar, in Aristotle, is the central component of a specific theorizing of the function of tragedies and epics. This functionalization has, however, been rendered obsolete by the historical process.

In order not to neglect the second part of my paper, namely, the question of what has become of this syndrome of verisimilitude and literature in more recent times, I will only briefly characterize the further steps of Aristotle's comprehensive theory concerning the function of literary texts: an ingredient no less difficult to understand than the ones discussed previously is the rules he advises for the construction of well-conceived central personages, or, heroes. At times he seems

5 See Roland Barthes. S/Z. Paris: Seuil, 1970.

6 - these are the words advanced by the text's narrator in the second chapter of Le Père Goriot. The quotation continues: “[...] il est si véritable que chacun peut en reconnaître les éléments chez soi [...]" (Honoré de Balzac. Le Père Goriot. La Comédie humaine, edited by Marcel Bouteron, vol. 2. Paris: Gallimard, 1963, pp. 847-1085, p. 848).

7 - with the exception, perhaps, of Frédéric's inheritance, which is, this should not be forgotten, the basis of his unproblematic, although somewhat uneventful - and in that sense: verisimilar existence of over two decades as narrated in the penultimate chapter. 
to have in mind characters far more outstanding than regular humans (epieikês); at times he says that heroes need not be better than common human beings. ${ }^{8}$ In any case, he claims that the hero should be hómoion - equal, comparable - to the spectators.

It seems that we find a first solution to the difficult question of why there was, 2,500 years ago, a theorizing of literary texts which is at first sight so very close to positions we are familiar with from nineteenth-century poetology, in those passages where Aristotle begins to discuss the effects of a well-wrought tragedy: it is to arouse phóbos and éleos. But it is not the arousal that is the final goal, it is rather the purification, or, as I would rather say, the evacuation of these affects, that constitutes the final point, as well as the pleasure that accompanies this kátharsis.

What is the logic behind this rather odd theorizing? - it is a literary text's primary function to first stimulate and then evacuate certain specific emotions. I would suggest taking a look at the question for whom the playwrights of that age conceived their pieces. The recipients were not a general public in the modern sense, they were constituted by the (male) adult full citizens, that is, those allowed but also obliged to carry arms - which means at the same time that they were obliged to fight for the polity, should this become necessary.

In order to complete the panorama of the elements on which Aristotle's theory builds one has to add that the Stagirite polemically engages his teacher Plato with respect to the nature of the affects. While Plato holds that affects can be disciplined and even totally controlled by reason, Aristotle considers such a view to be one of the many illusions concerning humans that would only come to the mind of a theorizer. Aristotle was the son of a physician, and in many respects his anthropology is much more materialistic, physical, than Plato's. Affects are, according to the Stagirite, bodily reactions to external stimuli which occur without the intervention of volition. According to a conceptualization that has been handed down to us by Galenic humoral pathology, the concrete intensity of the affective reaction is contingent upon the configuration of the various bodily fluids in a certain specific person. To put it very concisely: to artificially arouse and then cathartically purge certain specific affects might help reduce the quantity of bodily fluids prone to arousal. To put it in more concrete terms: periodically submitting the warrior class of Athens to artificially feeling fear and pity may have helped to immunize them against feeling fear and pity when fighting on a real, factual battle-field. Verisimilitude with respect to the action, and homoiôsis with regard to the hero of a tragedy are thus to be conceived as the structural enabling of identification, which is an indispensable prerequisite of emotionalization.

8 Meaning of course: humans from the ruling class, I shall come back to this point. 
When we now risk an audacious jump right into the eighteenth century, it should not astonish us that very many details regarding the theorizing of drama and epics have changed. But it is interesting to observe that many arguments were continued while being given an, at times, completely different meaning. ${ }^{9}$ When Balzac frequently calls his novels "drame," 10 he is referring to a generic label introduced by Denis Diderot in his reflections concerning the problem of how a tragedy adapted to modern times might best be conceived. In the Entretiens sur 'Le Fils naturel' (1757) and in the Discours sur la poésie dramatique (1758), Diderot continues the Aristotelian argument that it is the primary goal of drama to emotionalize the spectators. His concept of "emotions" is, however, much broader than the Aristotelian reduction to phóbos and éleos. It also comprises less intense affects like sympathy and empathy. Diderot's most important argument for creating a substitute for the (according to him) obsolete genre of tragedy is linked to the recipients he has in mind: why should late eighteenth-century middle-class Parisians be emotionalized when confronted with situations pertaining specifically to the lifeworld of princes and kings, with regard to which they had become more and more critical, if not hostile, in the process of political enlightenment? Some decades later, it was François-René de Chateaubriand who gave the most impressive characterization of this shift in literary demand linked to a shift in the audience, the latter being contingent on a dramatic political shift, namely the abolition of the feudal system: “Avant la Révolution, on n'interrogeait les manuscrits que relativement aux prêtres, aux nobles et aux rois. Nous ne nous enquérons que de ce qui regarde les peuples et les transformations sociales."11

Diderot, for his part, invested some energy in theorizing what the preconditions are for an arousal of emotion linked to situations borrowed from the lifeworld, no longer of kings, but of bourgeois people. Is it possible to feel deeply shocked by the vicissitudes ascribed to a humble "père de famille" (this is the title of one of Diderot's drames, created in 1758), rather than to a king whose horrible, but unconscious past mistakes lead the entire polis into destabilization and a foreseeable disaster? Diderot's answer, once again, has recourse to basic arguments already found in the Poetics, while, once again, changing the relative

9 See Hans Robert Jauss. "Diderots Paradox über das Schauspiel (Entretiens sur 'Le Fils naturel').” Germanisch-Romanische Monatsschrift 42 (1961), pp. 380-413; see also my Ästhetik der Wirklichkeitsdarstellung und Evolution des Romans von der französischen Spätaufklärung bis zu Robbe-Grillet. Stuttgart: Steiner, 1987, chs. I-IV.

10 See the reference in n. 6.

11 François-René de Chateaubriand. "Preface." Études historiques. Euvres complètes, vol. 9. Paris: Garnier, 1861, pp. 5-99, p. 29. Chateaubriand's observation is all the more remarkable as he was, as to his political opinions, a fierce reactionary. 
weight of the argument in question. As already explained, Aristotle indeed emphasizes that there is a prerequisite for empathy, namely the possibility on the recipients' part of considering themselves as hómoion ${ }^{12}$ - that is: equal or similar - to the tragic hero. It seems that in Aristotle this clause is mainly meant to refer to the psychic and intellectual profile of the hero, and not primarily to his social status. That said, the "democratic" Athens of the fifth century BCE was structured in a way that differs dramatically from Europe in the eighteenth and nineteenth centuries CE. The audience of the classical Greek tragedy performances was patrician. The distance between their lifeworld and the situations represented on stage was factual, but it was not unbridgeable, at least not in terms of imaginary identification. Things were drastically different in Europe in the age of absolutism. Bourgeois (tiers état) people's lifeworld experience was so far removed from the life at court that emotional identification may have been a difficult thing. And the closer we get to the actual revolution of 1789 , the more there may have been a conscious unwillingness on the tiers état's part to identify with the stage analogues of people whom they considered to be oppressors and decadent profligates. Consequently, Diderot proposes that the genre of drame, that is, modern-style tragedy, should present "dramatic" scenes of bourgeois life.

Still, there is the question of how to reach a level of identification that is sufficient to provoke empathy, emotion. Is everyday misery (looming bankruptcy, the pregnancy of an unmarried daughter, ${ }^{13}$ etc.) apt to provoke emotions in the audience? Diderot's answer to the question is inspired by the novels by Samuel Richardson. ${ }^{14}$ Without disclosing to his readers the rationale of so doing, Richardson distinguishes, according to Diderot, his écriture, as regards the setting in which the action of novels like Pamela (1740) and Clarissa (1748) takes place, by a peculiar feature, namely a "multitude de petites choses [auxquelles] tient l'illusion; il y a bien de la difficulté à les imaginer." 15 The effect of all these - at first sight contingent, that is, meaningless - details is, according to Diderot, the impression, on the recipients' part, that the entire action is not something invented, something fictional, but something real. ${ }^{16}$ It is no longer the immensity of catastrophe that provides the basis for the recipients' emotional arousal; it is the "reality effect,"

12 Aristotle, Poetics, 1453a 4-6 (see also 1454a 24).

13 I am referring not only to Diderot's, but also to Mercier's contributions to the new genre.

14 On his Éloge de Richardson (1762), see my Ästhetik der Wirklichkeitsdarstellung, pp. 13-55.

15 Denis Diderot. Éloge de Richardson. Euvres esthétiques, edited by P. Vernière. Paris: Garnier, 1959, p. 29-48, pp. 35.

16 Let me add in parenthesis that Roland Barthes built his theory of literary realism as developed in his famous essay “L'Effet de réel” (first printed in Communications 11 [1968], pp. 84-89) on this argument first advanced by Diderot. 
the conviction that "all [this] is true,"17 that provides the emotional engagement that is a prerequisite for the readers' positive response to a given text.

To summarize: it seems that literary realism's most conspicuous device, namely substituting the novel for tragedy, owes its "origins" to a shift in the recipients of literary products, a shift that occurred in the eighteenth century, especially in its pre-revolutionary second half. The quantitatively dominant part of the demand side of the emerging modern book-market was constituted by the bourgeois class, whose members attained literacy during that century. The demand of these new recipients could no longer be satisfied by the "old" genre of classical and classicist tragedy, which seemed all too different from eighteenth-century bourgeois lifeworld experience to be able to provoke emotions. The "new" genre of drame, proposed by Diderot as an adequate substitute, is, according to the theoretician, a combination of tragedy and comedy. ${ }^{18}$ From comedy it takes the setting of everyday bourgeois life; from tragedy it adopts the element of disaster hitting the principal personages. The question of identification on the recipients' part - provided for within the reception process of classical tragedies by the narcissistically fueled imaginary "bridging" of the gap between kings and patrician audience - is resolved by "lowering" the impression of fictionality and by increasing the level of alleged "reality." This should be done, according to Diderot, by way of creating reality-effects based on an accumulation of descriptive details without an obvious function in the narrative as a whole.

If one accepts this position, it is evident that drama as a genre characterized by a relatively reduced quantity of descriptive passages can no longer be the adequate generic frame for this "new" variant of tragedy. But it was not Diderot himself 19 who put into practice the ideas first devised by him. The "new" technique of how to create identification under the conditions of a post-heroic society, to be found in a somewhat embryonic stage in Richardson, was systematically implemented only from the time of Balzac, who extracted the specific descriptive techniques from a pragmatic genre that already existed, the Mercier-style Tableau de Paris which, while based on the classical genre of "praise of one's (native) city," is distinguished from its model by focusing on the "interesting," "curious" features of present-day city-life, thus catering to the needs of a "new" readership which, on account of its social position, was no longer interested in questions of origin and provenance but was, rather, looking to be presented with its own everyday world as a scene or

17 - to quote, once again, from Balzac's Le Père Goriot (see n. 6).

18 See Denis Diderot. Entretiens sur 'Le Fils naturel.' CEuvres esthétiques, edited by Paul Vernière. Paris: Garnier, 1959, pp. 77-175. On the description of drame, see specifically pp. 137-140.

19 - who, as said, tried to conceive some pieces according to his theorizing of the shift in recipients, but was not very successful as a dramatist. 
a stage.$^{20}$ As a result of all these processes of extraction-from-the-archive, recombination, and refunctionalization, there is, finally, the "new" genre of the realistic novel with its accent on literary topography.

In conclusion, I should like to summarize my argument while relating it to the general topic of this volume: Aristotle does not propagate, but permits the integration of history into drama, though with the qualification that only such episodes of what did factually occur may be selected that comply with or allow for modeling according to the standards of verisimilitude. Early modern European drama, heavily influenced by Neo-Aristotelian poetology, made use of Aristotle's position in order to create historical dramas, mainly tragedies, while relegating to the background the strict rules concerning the presence of history in drama as established by Aristotle. The best examples of the latter attitude may be Shakespeare's histories that present history in the same way as it is already conceived by Aristotle, that is, as a contingent chain of events, which implies that the pieces build upon a material that, according to the Stagirite, is not suitable for constructing well-wrought plays. The "more general" meaning they thus convey is, accordingly, the one contained in the structuring of the plot: factual history is the realm of inscrutable contingency, "signifying nothing," to quote Macbeth, a nihilistic attitude Aristotle would have most probably rejected, if only for ethical reasons.

This model of early modern historical tragedy loses ground with the inception of the bourgeois age. For the reasons explained previously, identification as the basic device for engaging the recipients gets replaced by illusion. The latter effect is created mainly by integrating a huge amount of descriptive detail into the stories, which means at the same time that drama as the "leading" genre gets replaced by the novel.

Description, however, links a narrative to a certain specific time and place, which means that history becomes, once again, a central topic in "modern-style" tragedies, that is, in realistic novels. The question already hinted at in Aristotle's text remains open, however. The modeling of history is either submitted to the structuring principle of the fiction created by the narrator (or author), which means, as can be seen most prominently in Balzac, that it becomes distorted. Or, as may be seen in Flaubert, history is preserved in its essential inscrutability, which, as such, undermines the pertinence of the fictional narrative: why invent something futile, if reality as such is futile all the way? With hindsight, the skeptical attitude towards a fusion of history and fiction, as displayed by Aristotle, seems to be a very sound position.

20 - a mentality that later became the basis of the middle-class style of tourism. 